\title{
Improving the Spectral Response of Black Dye by Cosensitization with a Simple Indoline Based Dye in Dye-Sensitized Solar Cell
}

\author{
Md. Akhtaruzzaman, ${ }^{1}$ Ashraful Islam, ${ }^{2}$ Mohammad Rezaul Karim, ${ }^{3}$ \\ A. K. Mahmud Hasan, ${ }^{1}$ and Liyuan Han ${ }^{2}$ \\ ${ }^{1}$ Department of Chemistry, Faculty of Science, University of Malaya, 50603 Kuala Lumpur, Malaysia \\ ${ }^{2}$ Photovoltaic Materials Unit, National Institute for Materials Science, 1-2-1 Sengen, Tsukuba, Ibaraki 305-0047, Japan \\ ${ }^{3}$ Center of Excellence for Research in Engineering Materials (CEREM), College of Engineering, King Saud University, \\ Riyadh 11421, Saudi Arabia
}

Correspondence should be addressed to Md. Akhtaruzzaman; akhtar@um.edu.my

Received 29 June 2012; Accepted 28 August 2012

Academic Editor: Ahmed El-Shafei

Copyright (c) $2013 \mathrm{Md}$. Akhtaruzzaman et al. This is an open access article distributed under the Creative Commons Attribution License, which permits unrestricted use, distribution, and reproduction in any medium, provided the original work is properly cited.

Indoline dye D-1 was successfully applied as a cosensitizer for improving the spectral response of black dye in dye-sensitized solar cells (DSCs). It was observed that D-1 effectively increases the short-circuit photocurrent by offsetting the competitive light absorption by $\mathrm{I} / \mathrm{I}_{3}{ }^{-}$electrolyte in the wavelength region $350-500 \mathrm{~nm}$ when adsorbed on the $\mathrm{TiO}_{2}$ nanocrystaline films in a mix dye system. The DSCs containing the D-1 and black dye achieved a power conversion efficiency of $9.80 \%$ with higher short-circuit photocurrent of $19.54 \mathrm{~mA} / \mathrm{cm}^{2}$ compared to the system of black dye without cosensitization under standard AM 1.5 sunlight.

\section{Introduction}

Dye-sensitized solar cells (DSSC) based on nanocrystalline $\mathrm{TiO}_{2}$ electrodes are promising candidate for low-cost alternative energy sources compared to silicon and other inorganic semiconductor-based photovoltaic devices [1-5]. Therefore, many researchers have continued their tremendous efforts over the last two decades for improving the performances of DSCs [6-9]. In DSCs, a sensitizing dye adsorbed at the surface of a wide band gap semiconductor (usually nanostructured $\mathrm{TiO}_{2}$ ) absorbs light to transfer an electron to the semiconductor conduction band, followed by dye regeneration by a solution redox electrolyte or a solid hole conductor. The most common and efficient dyes employed so far in these solar cells are $\mathrm{Ru}(\mathrm{II})$ polypyridyl complexes as their intense charge-transfer (CT) absorption in the whole visible range, high quantum yield for the formation of the lowest CT excited state, and ease to tune redox properties [10-18]. The photoexcitation of the metal-to-ligand chargetransfer (MLCT) excited states of the adsorbed dye leads to an efficient injection of electrons into the conduction band of $\mathrm{TiO}_{2}$. Up to now, the highest conversion efficiency $(\eta)$ from solar light to electric power for DSCs is over $11 \%$ under standard AM 1.5 conditions, which has been obtained from porous $\mathrm{TiO}_{2}$ electrode using Ru polypyridine complexes (black dye) as sensitizers, and an organic electrolyte containing $\mathrm{I}^{-} / \mathrm{I}_{3}{ }^{-}$as a hole transport media [7]. However, the conversion efficiency of DSCs is still lower than that of the silicon-based photovoltaic cells. It will be required to improve the light harvesting efficiency in the near-IR region as well as over the entire visible region of the solar spectrum to further improve the conversion efficiency. Black dye based DSCs show a strong dip at about $380 \mathrm{~nm}$ in the incident photon-to-current conversion efficiency (IPCE) spectrum due to the competitive light absorption of the triiodide and black dye. To overcome this problem, recently a mix dyes system has been used to avoid the competitive adsorption and aggregation among dyes that may induce unfavorable charge or energy transfer and quenching of photo-excited states $[8,9]$. Although the efficiency of black dye increased with the combination of an organic dye, the mechanism and selection of this dye in that system has yet to be clear. 
To understand this system and effectiveness, here, we have strategically chosen dye D-1 (Figure 1) as a cosensitizer considering its strong light harvesting efficiency at around $400 \mathrm{~nm}$ and also studied its performance with the black dye in mix dye-sensitized DSCs.

\section{Experimental Section}

All reagents were purchased from Sigma-Aldrich and Alfa Aesar. The dye D-1 was synthesized according to the published method [19]. Absorption spectra were recorded on a Shimadzu model 3100 UV-Vis-NIR spectrophotometer. Nanocrystalline $\mathrm{TiO}_{2}$ films were prepared by using a variation of a reported method [20]. TCO glass electrodes with a sheet resistance of $8-10 \mathrm{ohm}^{-2}$ and an optical transmission of greater than $80 \%$ in the visible range were used. A double-layer $\mathrm{TiO}_{2}$ photoelectrode $(15+5) \mu \mathrm{m}$ in thickness with a $15 \mu \mathrm{m}$ thick nanoporous layer and a $5 \mu \mathrm{m}$ thick scattering layer (area: $0.25 \mathrm{~cm}^{2}$ ) was prepared by screen printing on a conducting glass substrate. The films were then sintered at $500^{\circ} \mathrm{C}$ for 1 hour. The thickness of films was measured with a Surfcom 1400A surface profiler (Tokyo Seimitsu Co. Ltd.). The films were further treated with $0.1 \mathrm{M}$ $\mathrm{HCl}$ aqueous solutions before examination [21]. A mixture of black dye (tri(thiocyanato) $\left(4,4^{\prime}, 4^{\prime \prime}\right.$-tricarboxy-2,2 $: 6^{\prime}, 2^{\prime \prime}$ terpyridine)ruthenium(II)) $(0.2 \mathrm{mM})$ and D-1 (0.1 $\mathrm{mM})$ with addition of deoxycholic acid at a concentration of $20 \mathrm{mM}$ in $1: 1$ acetonitrile and tert-butanol was used as a mix dye solution. The $\mathrm{TiO}_{2}$ films were immersed in the above solutions and then kept at $25^{\circ} \mathrm{C}$ for 30 hours. The dye deposited $\mathrm{TiO}_{2}$ film and a platinum-coated conducting glass were separated by a Surlyn spacer ( $40 \mathrm{~mm}$ thick) and sealed by heating the polymer frame. An electrolyte consisting of a solution of $0.6 \mathrm{M}$ dimethylpropyl-imidazolium iodide, $0.05 \mathrm{M} \mathrm{I}_{2}, 0.1 \mathrm{M} \mathrm{LiI}$, and $0.4 \mathrm{M}$ tert-butylpyridine in acetonitrile was used in all the cells.

The current-voltage characteristics were measured using a black metal mask with an aperture area of $0.25 \mathrm{~cm}^{2}$ under standard air mass 1.5 sunlight $\left(100 \mathrm{~mW} \mathrm{~cm}^{-2}\right)$. Monochromatic incident photon-to-current conversion efficiency spectra were measured with a monochromatic incident light of $1 \times 10^{16}$ photons $\mathrm{cm}^{-2}$ in direct current mode (CEP-2000BX). The photoemission yield curves were measured with an AC-3 photoelectron spectrometer surface analyzer under atmosphere with a $0.2 \mathrm{~mL} \mathrm{~min}^{-1} \mathrm{~N}_{2}$ flow.

\section{Results and Discussions}

Figure 2 shows the UV-visible absorption spectra of black dye, D-1, and triiodide in ethanol solutions. The cosensitizer D-1 showed strong absorptions near $440 \mathrm{~nm}$ with a high molar extinction coefficient $(\varepsilon)$ of $2.53 \times 10^{4} \mathrm{M}^{-1} \mathrm{~cm}^{-1}$. We assigned this absorption to the intramolecular charge transfer between the donors and the acceptors in D-1. The broad and intense visible bands of black dye in the 390-540 $\mathrm{nm}$ region are due to the metal-to-ligand charge transfer transitions. As shown in Figure 2, D-1 shows a superior light harvesting efficiency in the wavelength region of 400-500 nm compared to that of black dye and $\mathrm{I}_{3}{ }^{-}$. Compared to the molar extinction coefficients of $\mathrm{I}_{3}{ }^{-}$, D-1 showed much higher light harvesting ability in this region which may attribute to the loss of the light absorption by $\mathrm{I}_{3}{ }^{-}$to be suppressed by the use of cosensitizer D-1.

Figure 3 shows the absorption spectra of black dye, D-1, and a mixture of black dye and D-1 absorbed on transparent thin film of nanoporous $\mathrm{TiO}_{2}(4 \mu \mathrm{m})$. Both $\mathbf{D}$-1 and black dye showed broad absorption spectra similar to that in solution. However, the absorption maxima were slightly blue-shifted due to the interaction between the carboxylate group and $\mathrm{TiO}_{2}$ (Figure 3). Upon adsorption on $\mathrm{TiO}_{2}$ film, the tail of the absorption spectra of black dye and $\mathbf{D}-\mathbf{1}$ extended to $600 \mathrm{~nm}$ and $850 \mathrm{~nm}$, respectively. This broadening of the absorption spectra is desirable for harvesting the solar spectrum and leads to a higher photocurrent. The electronic absorption spectrum of $\mathbf{D}-\mathbf{1}$ adsorbed on $\mathrm{TiO}_{2}$ shows a well defined intense absorption band at around $430 \mathrm{~nm}$. The absorbance of this band is much higher than that for black dye at this wavelength. The absorption spectrum of mix dye $(\mathrm{BD}+\mathrm{D}-1)$ coated transparent $\mathrm{TiO}_{2}$ film shows a broad absorption band ranging from $340-650 \mathrm{~nm}$. As shown in Figure 3, it is clear that mix dye system shows superior light harvesting efficiency than black dye in the wavelength region $360-540 \mathrm{~nm}$. Therefore it is expected that mix dye sensitized DSCs show better incident photon-to-electron conversion efficiency (IPCE) compared to black dye based DSCs in $360-540 \mathrm{~nm}$ and also improve the dip at about $400 \mathrm{~nm}$ in the IPCE spectrum of black dye based DSCs due to the competitive light absorption of the triiodide ion.

The ionization potential (IP) of D-1 bound to nanocrystalline $\mathrm{TiO}_{2}$ film was determined by using the photoemission yield spectrometer. Ground-state oxidation potential (HOMO) values of $-6.11 \mathrm{eV}$ was obtained for sensitizers D-1. The HOMO energy level of D-1 was sufficiently low compared to the redox potential of $\mathrm{I}^{-} / \mathrm{I}_{3}{ }^{-}(-5.20 \mathrm{eV})$ for efficient regeneration of oxidized dye through reaction with iodide. The onset of the optical energy gap $\left(E_{0-0}\right)$ of $\mathbf{D}-\mathbf{1}$ was 2.38. The excited-state oxidation potential, LUMO, of sensitizer D-1 was $-3.73 \mathrm{eV}$, which lies above the conduction band edge $(-4.2 \mathrm{eV})$ of the nanocrystalline $\mathrm{TiO}_{2}$. Therefore, an efficient electron injection into the conduction band of $\mathrm{TiO}_{2}$ is expected to occur for sensitizer $\mathbf{D}-\mathbf{1}$.

Figure 4 shows the monochromatic incident photon to current conversion efficiency for DSCs based on black dye, D-1, and a mixture of black dye and D-1. The dye D-1 shows excellent sensitization of nanocrystalline $\mathrm{TiO}_{2}$ from 400 to $550 \mathrm{~nm}$ with a maximum value of $85 \%$ in the plateau region. Taking into account the reflection and absorption losses by the conducting glass, the photon to current conversion efficiency in this range reaches about 95\%. The IPCEs of D-1 in 370-510 $\mathrm{nm}$ are high in comparison with that of black dye. The cell with only black dye showed a broad IPCE spectrum extending across the whole visible range and into the near-IR region as far as $950 \mathrm{~nm}$ and displayed the highest IPCE value (73\%) in the wavelength range from 600 to $700 \mathrm{~nm}$ (Figure 4). The IPCE, in the wavelength range $350-450 \mathrm{~nm}$, was decreased due to competitive light absorption between $\mathrm{I}_{3}{ }^{-}$and the black dye. Addition of 


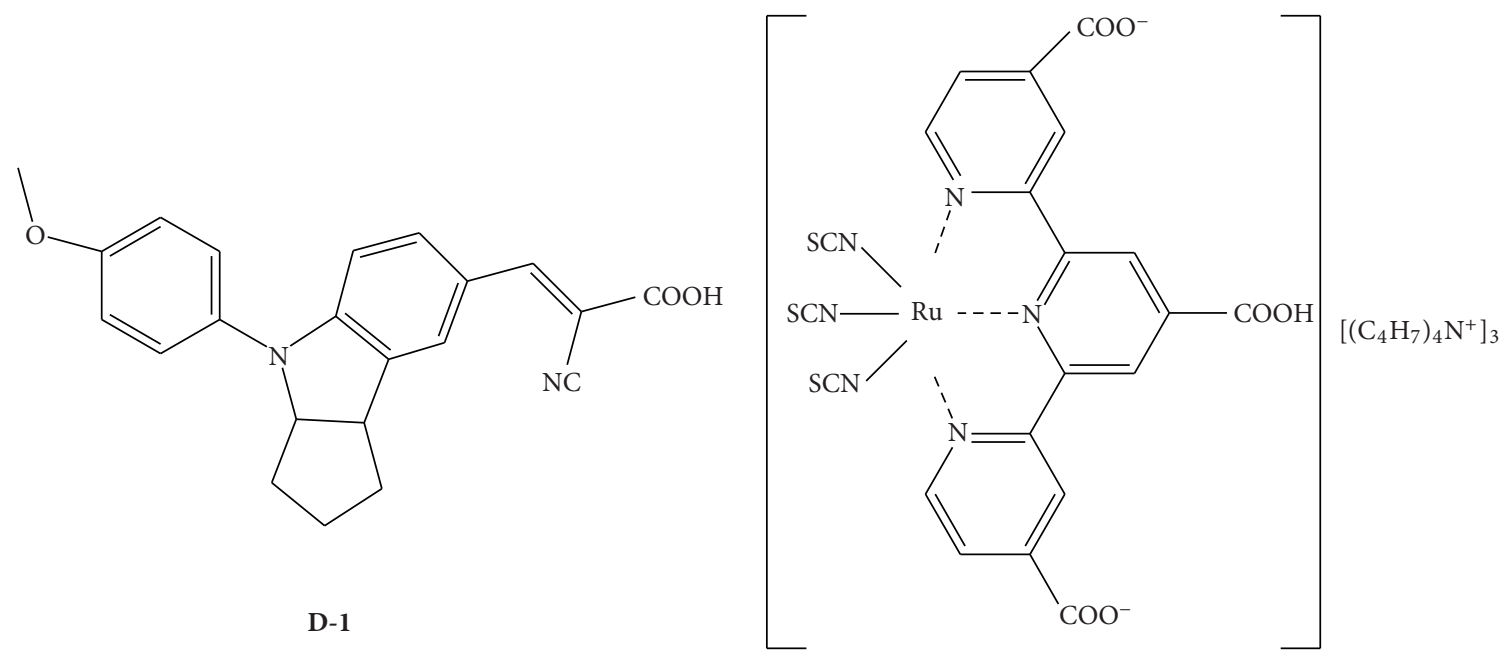

Black dye

FIGURE 1: Chemical structure of dye D-1 and black dye.

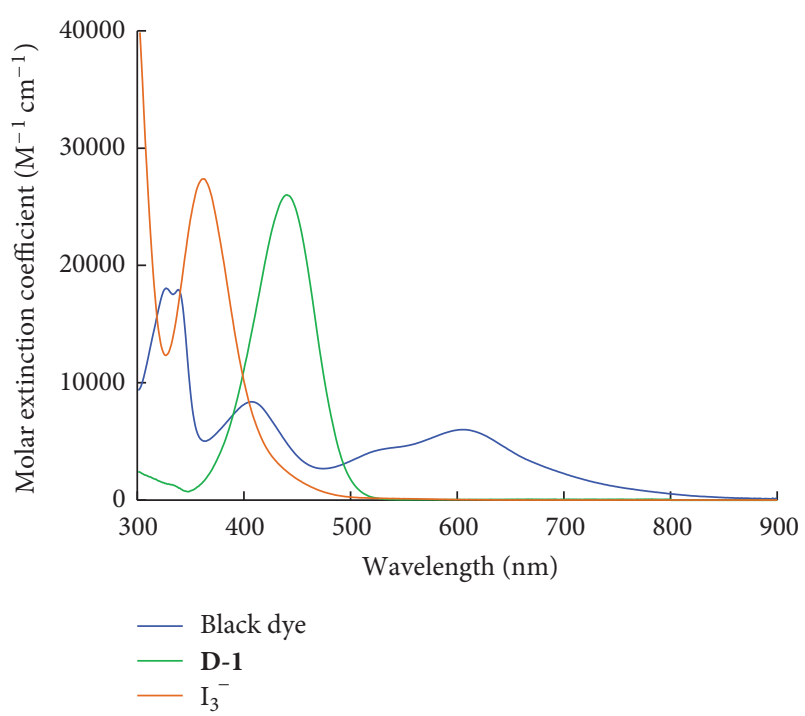

FIGURE 2: UV-visible absorption spectra of black dye, D-1, and triiodide in ethanol solutions.

cosensitizer D-1 for the cell with black dye enhanced the IPCE in the wavelength range $350-600 \mathrm{~nm}$. The dip in the IPCE spectra at around $400 \mathrm{~nm}$ was restored as shown in Figure 4 by adding the cosensitizer D-1 into the cells which indicates that the electron could easily inject from the D-1 into the $\mathrm{TiO}_{2}$ film in the mix dye sensitized DSCs. This result was consistent with the absorption spectrum of D-1. The IPCE spectra of black dye and mix dye sensitized DSCs were almost the same in the wavelength range 600-950 nm which indicates that both black dye and D-1 work independently with negligible interaction.

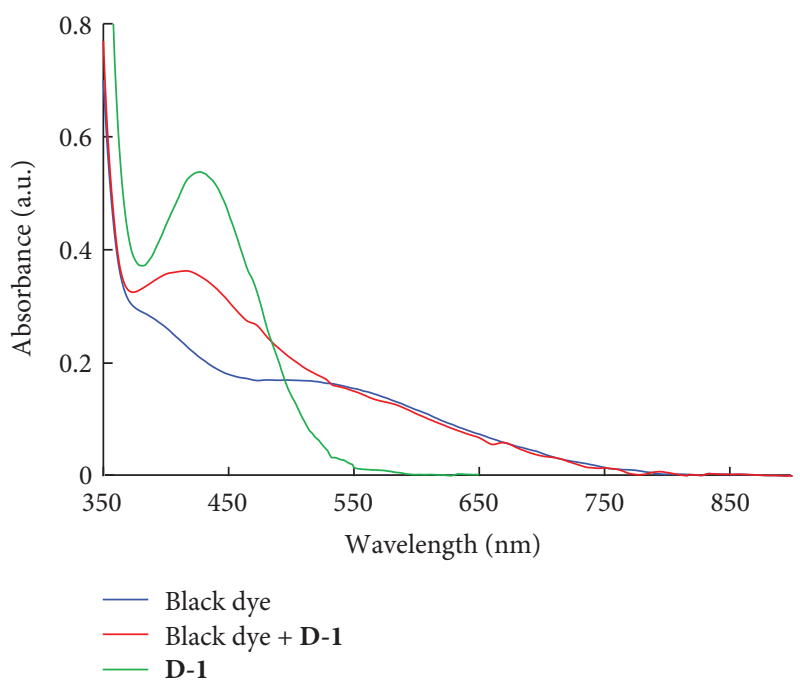

FIGURE 3: UV-visible absorption spectra of black dye, D-1, and black dye + D-1 (mix-dye) on $\mathrm{TiO}_{2}$ film.

Figure 5 shows the $I-V$ curves for DSCs based on black dye, D-1, and a mixture of black dye and D-1. The shortcircuit photocurrent density, open-circuit voltage, fill factors, and overall cell efficiencies for DSCs are summarized in Table 1. The mix dye sensitized solar cell showed higher power conversion efficiency than black dye, with $J_{\text {sc }}$ of $19.54 \mathrm{~mA}$ $\mathrm{cm}^{-2}, V_{\text {oc }}$ of $0.703 \mathrm{~V}$, FF of 0.714 , and corresponding to an overall conversion efficiency $(\eta)$ of $\mathbf{9 . 8 0} \%$. Under the same conditions, black dye showed a $J_{\mathrm{sc}}$ of $18.15 \mathrm{~mA} \mathrm{~cm}^{-2}, V_{\mathrm{oc}}$ of $0.704 \mathrm{~V}$, FF of 0.719 , and an overall conversion efficiency $(\eta)$ of $9.18 \%$. The improved photocurrent of mix dye sensitized solar cell relative to $\mathbf{D}-\mathbf{1}$ is in good accord with the proceeding IPCE measurements. 


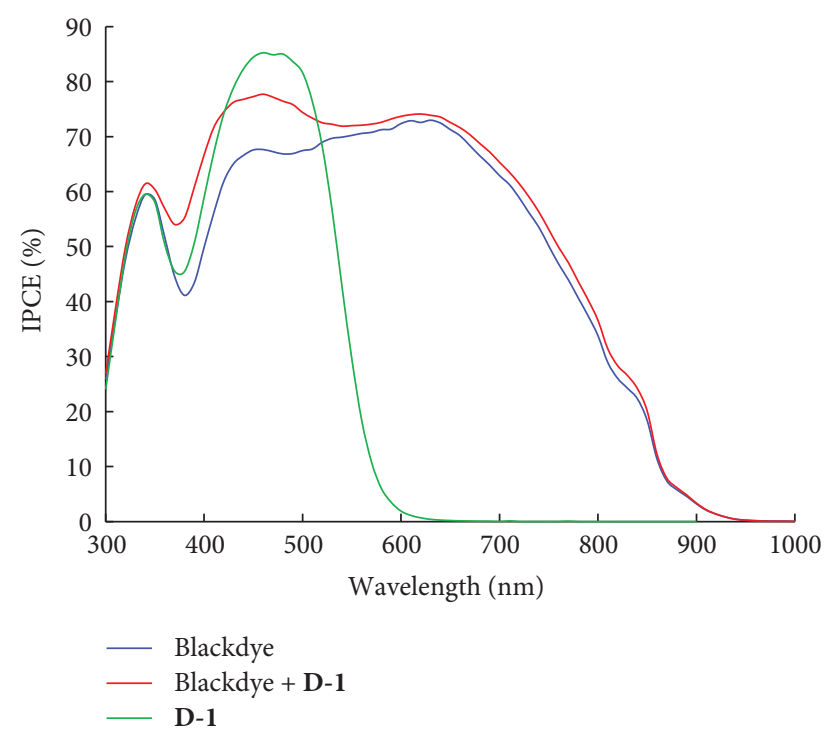

FIGURE 4: Incident photon-to-electron conversion efficiency (IPCE) spectra of DSCs.

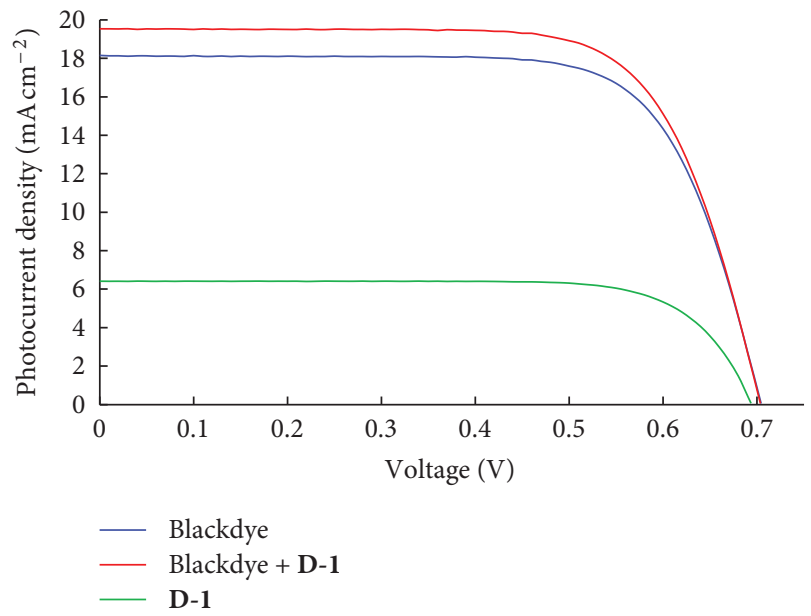

FIGURE 5: Current-voltage characteristics of the DSCs under AM1.5 sunlight illumination $\left(100 \mathrm{~mW} \mathrm{~cm}^{-2}\right)$.

TABLE 1: The current-voltage performance data of DSCs sensitized by black dye, D-1, and black dye + D-1 (mix-dye) measured AM1.5 sunlight illumination $\left(100 \mathrm{~mW} \mathrm{~cm}^{-2}\right)$.

\begin{tabular}{lcccc}
\hline Compound & $J_{\mathrm{sc}}\left(\mathrm{mA} \mathrm{cm}^{-2}\right)$ & $V_{\mathrm{oc}}(\mathrm{V})$ & FF & Eff. (\%) \\
\hline D-1 & 6.420 & 0.705 & 0.750 & 3.34 \\
Black-dye & 18.150 & 0.704 & 0.719 & 9.18 \\
Black-dye + D-1 & 19.540 & 0.703 & 0.714 & 9.80 \\
\hline
\end{tabular}

\section{Conclusion}

The combination of black dye and D-1 was found to exhibit improvement of cell efficiency by offsetting the competitive visible light absorption due to $\mathrm{I}_{3}{ }^{-}$. Addition of $\mathbf{D}-\mathbf{1}$ as a cosensitizer in the mix dye based DSC shows an enhanced IPCE in the wavelength range of 350-600 nm leading to an improved photocurrent. The distinct properties of $\mathbf{D}-\mathbf{1}$ as a cosensitizer enabled mix dye based DSCs to perform with high efficiency.

\section{Acknowledgment}

This work was partly supported by NPST Program by King Saud University of Project no. 10-NAN1021-02. The authors declare no conflict of interests.

\section{References}

[1] M. Gratzel, "Photoelectrochemical cells," Nature, vol. 414, pp. 338-344, 2001.

[2] B. O’Regan and M. Grätzel, "A low-cost, high-efficiency solar cell based on dye-sensitized colloidal $\mathrm{TiO}_{2}$ films," Nature, vol. 353, no. 6346, pp. 737-740, 1991.

[3] A. Hagfeld and M. Grätzel, "Molecular photovoltaics," Accounts of Chemical Research, vol. 33, no. 5, pp. 269-277, 2000.

[4] M. K. Nazeeruddin, F. De Angelis, S. Fantacci et al., "Combined experimental and DFT-TDDFT computational study of photoelectrochemical cell ruthenium sensitizers," Journal of the American Chemical Society, vol. 127, no. 48, pp. 16835-16847, 2005.

[5] A. Mishra, M. K. R. Fischer, and P. Bäuerle, "Metal-free organic dyes for dye-sensitized solar cells: from structure: property relationships to design rules," Angewandte Chemie, vol. 48, no. 14, pp. 2474-2499, 2009.

[6] A. Islam, H. Sugihara, and H. Arakawa, "Molecular design of ruthenium(II) polypyridyl photosensitizers for efficient nanocrystalline $\mathrm{TiO}_{2}$ solar cells," Journal of Photochemistry and Photobiology A, vol. 158, no. 2-3, pp. 131-138, 2003.

[7] Y. Chiba, A. Islam, Y. Watanabe, R. Komiya, N. Koide, and L. Han, "Dye-sensitized solar cells with conversion efficiency of 11.1\%," Japanese Journal of Applied Physics, vol. 45, no. 25, pp. L638-L640, 2006.

[8] L. Han, A. Islam, H. Chen et al., "High-efficiency dye-sensitized solar cell with a novel co-adsorbent," Energy \& Environmental Science, vol. 5, no. 3, pp. 6057-6060, 2012.

[9] H. Ozawa, R. Shimizu, and H. Arakawa, "Significant improvement in the conversion efficiency of black-dye-based dyesensitized solar cells by cosensitization with organic dye," RSC Advances, vol. 2, no. 8, pp. 3198-3200, 2012.

[10] R. Argazzi, C. A. Bignozzi, G. M. Hasselmann, and G. J. Meyer, "Efficient light-to-electrical energy conversion with dithiocarbamate-ruthenium polypyridyl sensitizers," Inorganic Chemistry, vol. 37, no. 18, pp. 4533-4537, 1998.

[11] T. A. Heimer, C. A. Bignozzi, and G. J. Meyer, "Molecular level photovoltaics: the electrooptical properties of metal cyanide complexes anchored to titanium dioxide," Journal of Physical Chemistry, vol. 97, no. 46, pp. 11987-11994, 1993.

[12] G. Sauvé, M. E. Cass, G. Coia et al., "Dye sensitization of nanocrystalline titanium dioxide with osmium and ruthenium polypyridyl complexes," Journal of Physical Chemistry B, vol. 104, no. 29, pp. 6821-6836, 2000.

[13] S. Ferrere, "New photosensitizers based upon $\left[\mathrm{Fe}(\mathrm{L})_{2}(\mathrm{CN})_{2}\right]$ and $\left[\mathrm{Fe}(\mathrm{L})_{3}\right]\left(\mathrm{L}=\right.$ substituted $2,2^{\prime}$-bipyridine): yields for the photosensitization of $\mathrm{TiO}_{2}$ and effects on the band selectivity," Chemistry of Materials, vol. 12, no. 4, pp. 1083-1089, 2000.

[14] G. M. Hasselmann and G. J. Meyer, "Sensitization of nanocrystalline $\mathrm{TiO}_{2}$ by $\mathrm{Re}(\mathrm{I})$ polypyridyl compounds," Zeitschrift für Physikalische Chemie, vol. 212, part 1, pp. 39-44, 1999. 
[15] N. Alonso-Vante, J. Nieregarten, and J. Sauvage, "Spectral sensitization of large-band-gap semiconductors (thin films and ceramics) by a carboxylated bis(1,10-phenanthroline)copper(I) complex," Journal of the Chemical Society, Dalton Transactions, no. 11, pp. 1649-1654, 1994.

[16] A. Juris, V. Balzani, F. Barigelletti, S. Campagna, P. Belser, and A. von Zelewsky, "Ru(II) polypyridine complexes: photophysics, photochemistry, eletrochemistry, and chemiluminescence," Coordination Chemistry Reviews, vol. 84, no. 1, pp. 85-277, 1988.

[17] K. Kalyanasundaram, "Photophysics, photochemistry and solar energy conversion with tris(bipyridyl)ruthenium(II) and its analogues," Coordination Chemistry Reviews, vol. 46, pp. 159-244, 1982.

[18] A. Islam, N. Ikeda, A. Yoshimura, and T. Ohno, "Nonradiative transition of phosphorescent charge-transfer states of ruthenium(II)-to-2,2' -biquinoline and ruthenium(II)-to$2,2^{\prime}: 6^{\prime}, 2^{\prime \prime}$-terpyridine in the solid state," Inorganic Chemistry, vol. 37, no. 12, pp. 3093-3098, 1998.

[19] M. Matsui, T. Fujita, Y. Kubota et al., "Substituent effects in a double rhodanine indoline dye on performance of zinc oxide dye-sensitized solar cell," Dyes and Pigments, vol. 86, no. 2, pp. 143-148, 2010.

[20] P. Wang, S. M. Zakeeruddin, P. Comte, R. Charvet, R. Humphry Baker, and M. Grätzel, "Enhance the performance of dyesensitized solar cells by co-grafting amphiphilic sensitizer and hexadecylmalonic acid on $\mathrm{TiO}_{2}$ nanocrystals," The Journal of Physical Chemistry B, vol. 107, no. 51, pp. 14336-14341, 2003.

[21] Z. S. Wang, T. Yamaguchi, H. Sugihara, and H. Arakawa, "Significant efficiency improvement of the black dye-sensitized solar cell through protonation of $\mathrm{TiO}_{2}$ films," Langmuir, vol. 21, no. 10, pp. 4272-4276, 2005. 

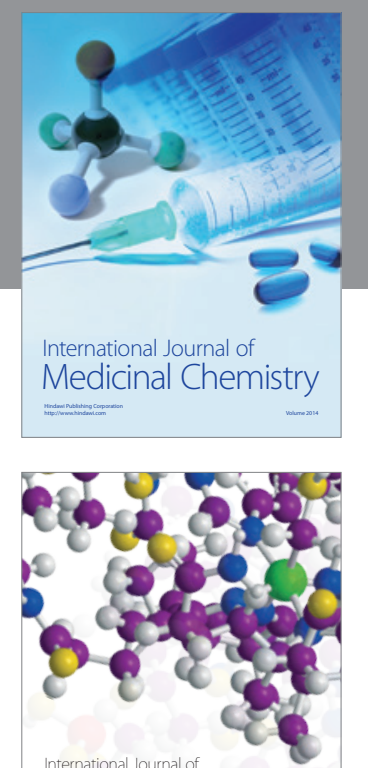

\section{Carbohydrate} Chemistry

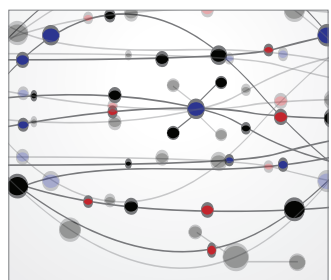

The Scientific World Journal
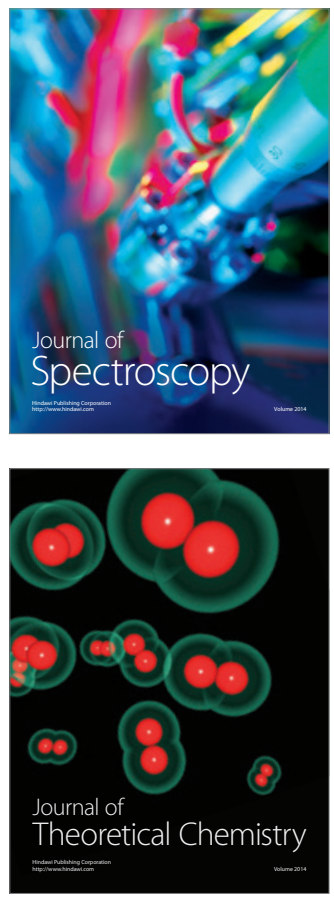
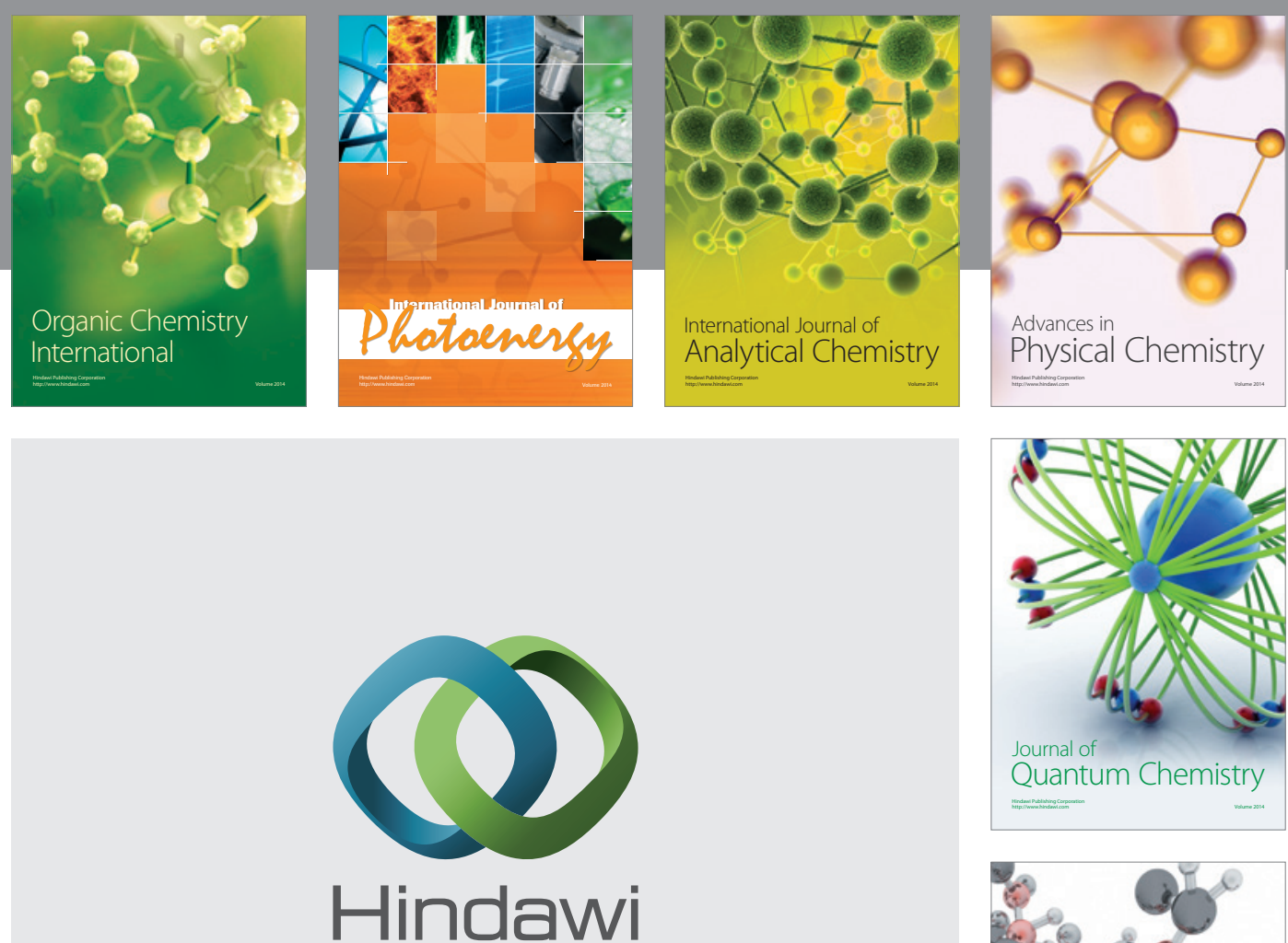

Submit your manuscripts at

http://www.hindawi.com

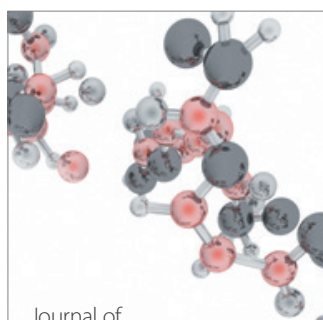

Analytical Methods

in Chemistry

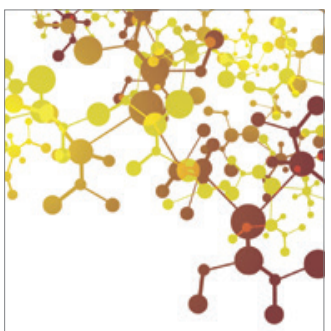

Journal of

Applied Chemistry

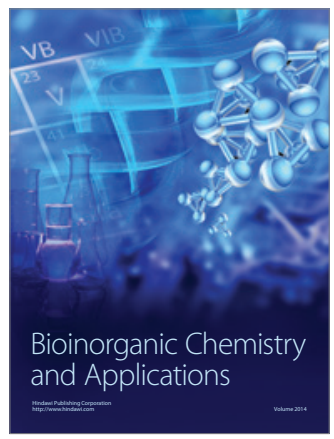

Inorganic Chemistry
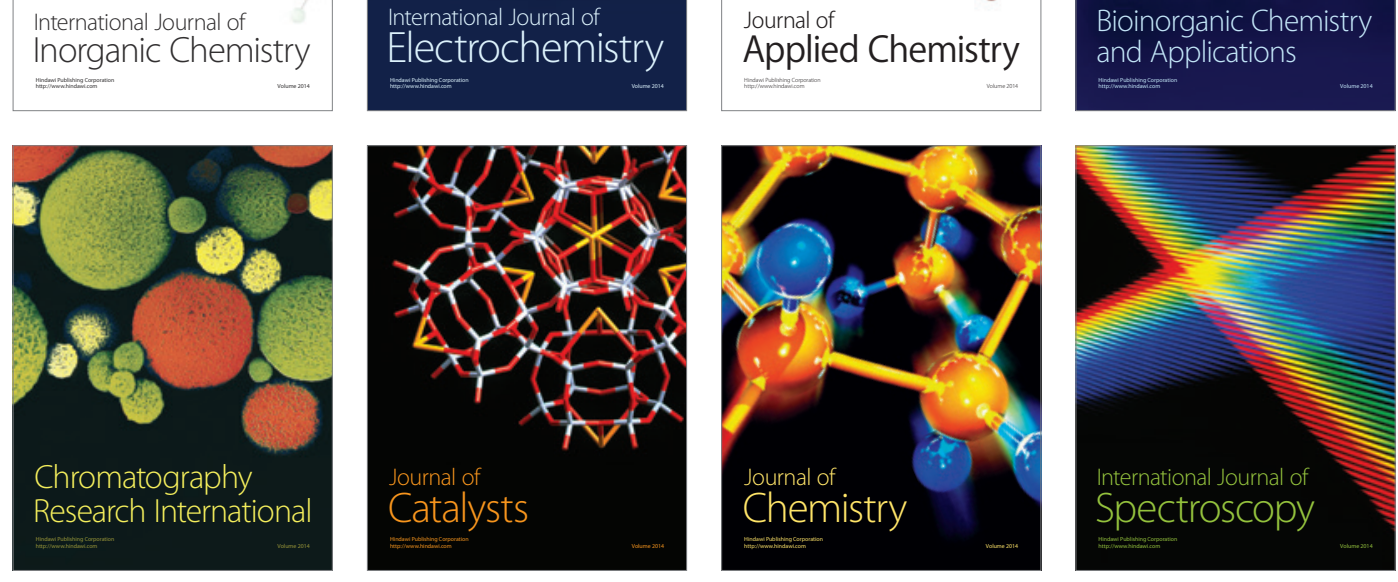